\title{
Experimental Analysis of Residual Stress in Multi-Component Coatings Deposited by PVD Method on Oxide Tool Ceramics
}

\author{
R. Dziwis, W. KWAŚNY*, A. Śliwa, \\ J. MikuŁA, B. Ziębowicz And J. ZaCŁonA \\ Department of Engineering Materials and Biomaterials, Silesian University of Technology, \\ Konarskiego 18a Str., 44-100 Gliwice, Poland \\ Doi: 10.12693/APhysPolA.138.320 \\ *e-mail: waldemar.kwasny@polsl.pl
}

\begin{abstract}
The purpose of this work is to determine the effect of application conditions on the structure and properties of multi-component coatings obtained in the Physical Vapour Deposition process on $\mathrm{Al}_{2} \mathrm{O}_{3}$ based oxide tool ceramic substrate. The tests were carried out on multi-edge cutting inserts made of $\mathrm{Al}_{2} \mathrm{O}_{3}+\mathrm{ZrO}_{2}$ oxide tool ceramics, coated with combinations of coatings based on ( $\left.\mathrm{Ti}, \mathrm{Al}, \mathrm{Si}\right) \mathrm{N}$ in the CAE PVD arc cathodic evaporation process. Based on the tests, the structure, phase composition and texture of the tested coatings were identified. The effect of stress values determined by the X-ray $\sin ^{2}(\psi)$ method on their microhardness and adhesion to the substrate material was determined.
\end{abstract}

topics: coating PVD, microhardness, adhesion, stress

\section{Introduction}

Nowadays, great importance is placed on the properties of materials. Depending on the needs, ceramic, metallic, polymer and composites materials are used [1-4]. Ceramic materials are quite interesting for many reasons.

Ceramic tool materials, especially those based on $\mathrm{Al}_{2} \mathrm{O}_{3}$, are an important group of engineering materials as they are characterised by high hardness, high mechanical strength at room temperature as well as low abrasion and the best chemical resistance compared to other tool materials [5-9].

Such favorable mechanical properties have great potential to determine the very strong position of oxide ceramics among tool materials. However, its unquestionable disadvantage and limitation in the further expansion of this material's range of applications is high brittleness, low bending strength and low thermal shock resolution [10-14].

The results of investigations on the possibilities of improving the functional properties of tool materials indicate that the deposition of coatings in physical vapour deposition (PVD) processes is most beneficial in this aspect [15-17].

If the surface machining technology of tools made of tool materials using PVD methods is employed to attain layers with high wear resistance, the properties of such materials can be enhanced, among others by lowering their friction factor, increasing microhardness, improving conditions of tribological contact within the zone of the machined item, as well as to improve protection against adhesion wear and diffusion [18-20].

\section{Materials}

The investigations were carried out on samples in the form of indexable inserts made of oxide tool ceramics based on $\mathrm{Al}_{2} \mathrm{O}_{3}+\mathrm{ZrO}_{2}$ coated with multicomponent coatings, such as $\mathrm{TiN}, \mathrm{TiN}+$ $(\mathrm{Ti}, \mathrm{Al}, \mathrm{Si}) \mathrm{N}, \mathrm{TiN}+(\mathrm{Ti}, \mathrm{Al}, \mathrm{Si}) \mathrm{N}+\mathrm{TiN}, \mathrm{TiN}+$ $(\mathrm{Ti}, \mathrm{Al}, \mathrm{Si}) \mathrm{N}+(\mathrm{Al}, \mathrm{Si}, \mathrm{Ti}) \mathrm{N},(\mathrm{Ti}, \mathrm{Al}) \mathrm{N}$ in the PVD cathodic arc evaporation process.

\section{Methodology}

X-ray tests of the analysed materials were carried out with an X'Pert device by Panalytical, using the filtered radiation of a lamp with a copper tube with $40 \mathrm{kV}$ voltage supply with $30 \mathrm{~mA}$ filament current intensity. X-ray phase qualitative analysis was carried out within the angle range $2 \Theta$ of $30^{\circ}$ to $105^{\circ}$, the step of 0.05 . The qualitative evaluation of the texture was performed using an Euler's disc with the diameter of $187 \mathrm{~mm}$ with the specimen inclination angles of 0 to $75^{\circ}$. The measurements of stresses of the analysed coatings were made with the $\sin ^{2}(\psi)$ technique based on XPert Stress Plus software incorporating - as a database - the values of material constants necessary for calculations. 
The thickness of the coatings was measured with a "kalotest" method consisting of measuring the characteristic sizes of a crater formed through wear on the surface of the specimen with a steel ball.

The observations of surface topography were made with the use of the AFM microscope from Park System X-E 100. The scanning range was 2, 5, and $10 \mu \mathrm{m}$.

The adhesion of the applied coatings was evaluated using the scratch-test method on the REVETEST device by CSEM, which consists in moving the diamond indenter along the surface of the specimen at a constant speed with the loading force rising proportionally to the movement.

Microhardness tests of the applied coatings were carried out on an ultra microhardness tester, DUH 202, by Shimadzu, with the Vickers method.

Surface roughness of the oxide ceramics samples with coatings deposited was measured in two mutually perpendicular directions with a Surftec $3+$ profilometer by Rank Taylor Hobson. The measurement length of $l=0.25 \mathrm{~mm}$ and the measurement accuracy of $\pm 0.01 \mu \mathrm{m}$ was assumed.

\section{Results}

An X-ray phase qualitative analysis performed with Bragga-Brentano geometry confirmed that on the analysed $\mathrm{Al}_{2} \mathrm{O}_{3}+\mathrm{ZrO}_{2}$-based tool ceramics substrate the following coatings were produced, respectively, TiN, TiN $+(\mathrm{Ti}, \mathrm{Al}, \mathrm{Si}) \mathrm{N}, \mathrm{TiN}+(\mathrm{Ti}, \mathrm{Al}$, $\mathrm{Si}) \mathrm{N}+\mathrm{TiN}, \mathrm{TiN}+(\mathrm{Ti}, \mathrm{Al}, \mathrm{Si}) \mathrm{N}+(\mathrm{Al}, \mathrm{Si}, \mathrm{Ti}) \mathrm{N}$ and (TiAl)N (Fig. 1). It was not possible to perform a full FRO analysis for the Bragg-Brentano symmetrical geometry used due to the overlapping of reflexes of the substrate material and the coating/coatings in most cases. A texture analysis allows to conclude, based on a qualitative analysis of the registered single polar figures (Fig. 2), that the differentiated growth plane for TiN and $\mathrm{Ti}(\mathrm{Al}, \mathrm{N})$ coatings is a plane from the $\{111\}$ family. The analysis of the polar figures of the other coatings shows that their texture is very weak (the density of the polar projections ranges from 0.9 to 1.1 of the density corresponding to the equally probable distribution).

Stress measurements of $\mathrm{TiN}, \mathrm{TiN}+(\mathrm{Ti}, \mathrm{Al}$, $\mathrm{Si}) \mathrm{N}$ and $(\mathrm{TiAl}) \mathrm{N}$ coatings were performed using the $\sin (2 \psi)$ method based on the reflex analysis (220) (Fig. 3). The angular position of the recorded reflexes was determined with the Gaussian curve adjustment method. In case of evaluation of the $\mathrm{TiN}+(\mathrm{Ti}, \mathrm{Al}, \mathrm{Si}) \mathrm{N}+\mathrm{TiN}$ and $\mathrm{TiN}+(\mathrm{Ti}, \mathrm{Al}$, $\mathrm{Si}) \mathrm{N}+(\mathrm{Al}, \mathrm{Si}, \mathrm{Ti}) \mathrm{N}$ coatings, the overlapping of reflexes of individual components of the investigated materials made it impossible to obtain correct measurement results and determine the stress values for the applied investigation technique.

Figures 4 and 5 show an image of surface topography of the (TiAl)N coatings obtained with an AFM microscope.

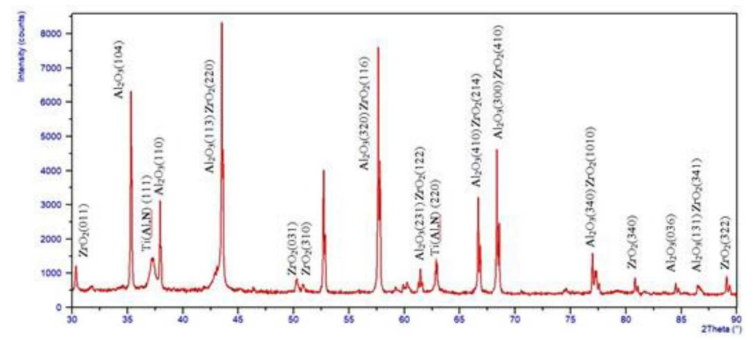

Fig. 1. Diffraction patterns of the (Ti, Al)N coating deposited on oxide ceramic tool materials substrate $\mathrm{Al}_{2} \mathrm{O}_{3}+\mathrm{ZrO}_{2}$.

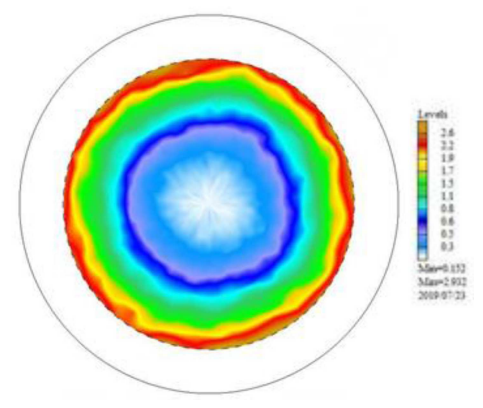

Fig. 2. Experimantal pole figures (220) of (Ti, $\mathrm{Al}) \mathrm{N}$ coating deposited on oxide ceramic tool materials substrate $\mathrm{Al}_{2} \mathrm{O}_{3}+\mathrm{ZrO}_{2}$.

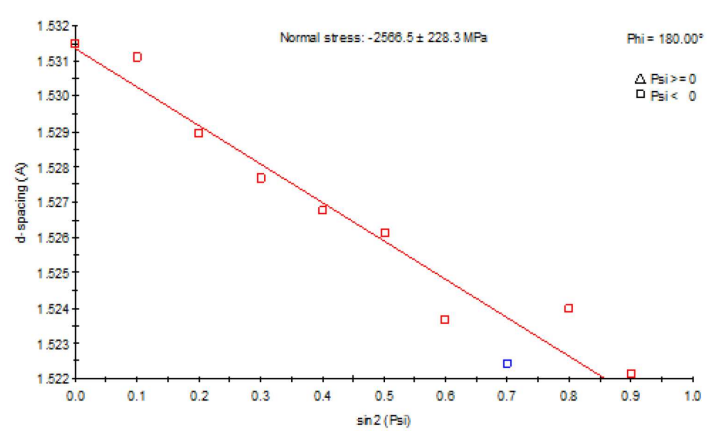

Fig. 3. Variations in the interplanar distance value $\mathrm{d}$ of reflex $(220)$ of the $(\mathrm{Ti}, \mathrm{Al}) \mathrm{N}$ coating in the function of $\sin (2 \psi)$.

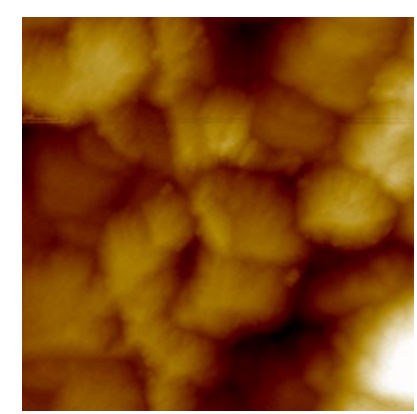

Fig. 4. Surface image of (TiAl)N coating made with the AFM microscope. Scanning range of $10 \mu \mathrm{m}$. 
Results of the measurement of mechanical properties of the analysed coatings.

TABLE I

\begin{tabular}{l|c|c|c|c|c}
\hline \hline \multicolumn{1}{c|}{ Coatings } & $\begin{array}{c}\text { Thickness } \\
{[\mu \mathrm{m}]}\end{array}$ & $\begin{array}{c}\text { Microhardness } \\
\text { HV } 0.07[\mathrm{GPa}]\end{array}$ & $\begin{array}{c}\text { Adhesion } \\
\text { Lc }[\mathrm{N}]\end{array}$ & $\begin{array}{c}\text { Roughness } \\
\text { Ra }[\mu \mathrm{m}]\end{array}$ & $\begin{array}{c}\text { Stresses } \\
{[\mathrm{MPa}]}\end{array}$ \\
\hline $\mathrm{TiN}$ & 0.8 & 22.7 & 45 & 0.37 & $-689 \pm 115.8$ \\
$\mathrm{TiN}+(\mathrm{Ti}, \mathrm{Al}, \mathrm{Si}) \mathrm{N}$ & 1.9 & 19.22 & 40 & 0.43 & $548 \pm 121.8$ \\
$\mathrm{TiN}+(\mathrm{Ti}, \mathrm{Al}, \mathrm{Si}) \mathrm{N}+\mathrm{TiN}$ & 2.3 & 40.9 & 76 & 0.37 & - \\
$\mathrm{TiN}+\mathrm{TiN}(\mathrm{Ti}, \mathrm{Al}, \mathrm{Si}) \mathrm{N}+(\mathrm{Al}, \mathrm{Si}, \mathrm{Ti}) \mathrm{N}$ & 2.2 & 21 & 78 & 0.40 & - \\
$(\mathrm{Ti}, \mathrm{Al}) \mathrm{N}$ & 2.2 & 32.9 & 82 & 0.23 & $-2566.5 \pm 228.3$
\end{tabular}

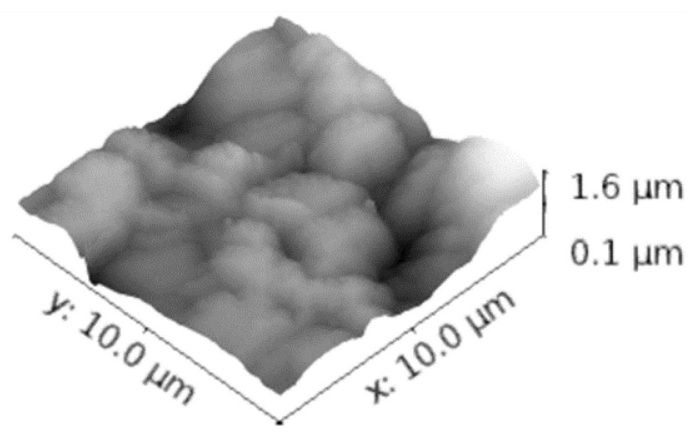

Fig. 5. Topography of (TiAl)N surface made with the AFM microscope. Scanning range of $10 \mu \mathrm{m}$.

It is difficult to indicate the difference between individual images of the analysed coatings by observing the surface topography of the analysed coatings, which was reflected in low values of the roughness parameter.

Table I presents the obtained results of measuring the mechanical properties and stresses of the analyzed coatings.

\section{Conclusion}

It was found based on the investigations conducted that the highest microhardness of $40.9 \mathrm{GPa}$ is exhibited by $\mathrm{TiN}+(\mathrm{Ti}, \mathrm{Al}, \mathrm{Si}) \mathrm{N}+\mathrm{TiN}$ coatings, whereas the lowest by 19.22 GPaTiN $+(\mathrm{Ti}$, $\mathrm{Al}, \mathrm{Si}) \mathrm{N}$ coatings.

The dependency between the value of stresses and the substrate adhesion of the investigated coatings is indicated by the results of the examinations of internal macrostresses for the analysed coatings. The coatings showing high adhesion to the substrate are characterised by high compressive stress values.

The observations of the analysed coatings' surface topography using the atomic force microscopy (AFM) methods reveal that the characteristic finish of the columns forming the respective coatings, observed on the surface, are in the shape of inverted pyramids, cones or craters characteristic for the PVD process.

No significant influence of the coating type on the roughness of the coating surface was found. The results obtained, depending on the material investigated, were in the Ra range from $0.23 \mu \mathrm{m}$ to $0.43 \mu \mathrm{m}$.

\section{References}

[1] J. Gondro, J. Świerczek, J. Olszewski, J. Zbroszczyk, K. Sobczyk, W. Ciurzyńska, J. Rzącki, M. Nabiałek, J. Magn. Magn. Mater. 324, 1360 (2012).

[2] K. Jez, M. Nabialek, K. Gruszka, M. Deka, S. Letkiewicz, B Jez, Mater. Plast. 55(3), 438 (2018).

[3] M. Nabialek, J. Fuzer, L. Dakova, P. Pietrusiewicz, Revista de Chimie 68, 1098 (2017).

[4] W. Musialik, M. Nabialek, S. Letkiewicz, A.V. Sandu, K. Bloch, Revista de Chimie 69, 840 (2018).

[5] K.-D. Bouzakis, G. Skordaris, S. Gerardis, G. Katirtzoglou, S. Makrimallakis, M. Pappa, Surf. Coat Technol. 204, 1061 (2009).

[6] M. Staszuk, D. Pakuła, T. Tański, Mater. Technol. 55, 75 (2016).

[7] M. Sroka, M. Nabiałek, M. Szota, A. Zieliński, Rev. Chim. 4, 737 (2017).

[8] M. Staszuk, D. Pakuła, G. Chladek, M. Pawlyta, M. Pancielejko, P. Czaja, Vacuum 153, 184 (2018).

[9] M. Staszuk, D. Pakuła, T. Tański, Mater. Technol. 55, 75 (2016).

[10] A. Śliwa, J. Mikuła, K. Gołombek, W. Kwaśny, D. Pakuła, Arch. Metall. Mater. 61, 1025 (2016).

[11] D. Pakuła , M. Staszuk, K. Gołombek, A. Śliwa, J. Mikuła, Arch. Metall. Mater. 61, 919 (2016).

[12] M. Bonek, A. Śliwa, J. Mikuła, Appl. Surf. Sci. 388, 174 (2016).

[13] A. Śliwa, W. Kwaśny, W. Sitek, M. Bonek, Arch. Metall. Mater. 61, 481 (2016).

[14] A. Śliwa, W. Kwaśny, M. Sroka, R. Dziwis, Metalurgija 56, 422 (2017).

[15] A. Śliwa, M. Bonek, Metalurgia 65, 223 (2017).

[16] A. Śliwa, M. Sroka, K. Bloch, J.G. Sandu, M.M. Al Bakri Abdullah, A.V. Sandu, Rev. Chim. 69, 324 (2018). 
[17] A. Śliwa, M. Sroka, L. Żukowska, K. Bloch, C. Vizureanu, A. Sandu, Rev. Chim. 69, 187 (2018).

[18] A. Śliwa, D. Gros, A.V. Sandu, M. Nabiałek, Rev. Chim. 69, 2813 (2018).

[19] L.A. Dobrzański, K. Gołombek, J. Mater. Process. Technol. 164, 805 (2005).

[20] L.A. Dobrzański, K. Gołombek, J. Kopač, M. Soković, Mater. Sci. Forum 437, 41 (2003). 